\title{
A Systematic Literature Review and Case Report of Bilateral Two- Rooted Mandibular Deciduous Canines and Their Usefulness in Forensic Identification
}

\author{
Liliana Marín ${ }^{1}$, Sandra Moreno ${ }^{2}$, and Freddy Moreno ${ }^{2 *}$ \\ ${ }^{1}$ Technical Criminal Investigative Body at Office of the Attorney General, Bogotá, Co- \\ lombia \\ ${ }^{2}$ Faculty of Health Sciences of Pontificia Universidad Javeriana Cali, Colombia
}

Keywords: forensic dentistry, dental identification, dental anthropology, deciduous tooth, canine teeth, two-roots

ABSTRACT A systematic review of the literature in PubMed was made by combining the terms "cuspid" and "tooth root" as MeSH health descriptors, combined with the Boolean operators " + " and " $\&$ " to obtain describing publications about two roots canines in order to sustain, on scientific evidence, the application of dental anthropology (dental morphological variations) in forensic science (forensic processes of dental identification). This literature review identified reports that describe the presence of two-rooted canines and the number and distribution of root canals for diagnostic and therapeutic purposes; and one report in which description was performed for forensic identification purposes. The descriptions corresponded to different cases of permanent maxillary canines with left unilateral expression, permanent mandibular canines with right unilateral expression, left unilateral expression with bilateral expression. There were no reports of deciduous dentition. Likewise, a case report in which skeletonized human remains were identified by the presence of bilateral two-root mandibular deciduous canines is described.

There are two maxillary and two mandibular canine teeth located on each hemi-arcade among the incisors and premolars (Kraus et al., 1969). The root of the maxillary canine is convex on its vestibular and lingual surface; its mesial and distal surfaces are broad and somewhat flattened; while the root of the mandibular canine is shorter and flatter with marked longitudinal grooves. The apical portions of the root could exhibit mesial drift, which may still have a bifurcation, making a double root (Hillson, 1996). Anatomically, the canines have a bulkier (in the vestibular-palatal or lingual) and longer root than the other teeth. This anatomy allows a strong anchor in the alveolar bone and gives a high resilience to forces generated in the masticatory cycle, depending on its high nociceptive capacity during the action of the muscles of mastication to sensory stimuli. This protection is achieved through the occlusal relationship between the maxillary and mandibular canines, in which, when the lateral movement of the mandible occurs the lower canines slide on the upper. This function is described in the literature as "canine function" or "canine key" to produce posterior teeth disclusion; hence, canines are seen as fundamental teeth of dental occlusion (Scott \& Turner, 1998). These morpho-physiological traits and strategic position in the maxillaries give the canine teeth high resistance; for this reason, they are the teeth with the lowest prevalence of loss. Therefore, canines have value in forensic odontological identification processes. In this context, dental anthropology through the characterization of individuals by analysis of expression and variation of root and coronal dental morphological traits is fundamental (Rodríguez \& Delgado, 2000).

In single-rooted teeth, as canines, the root sheath grows as a tube shape as radicular odontoblasts are differentiated. These odontoblasts regulate the process of dentinogenesis around the dental pulp, and are fragmented to allow the passage of cells that differentiate into cementoblasts from the dental follicle, which lead the process of cementogenesis. In multiradicular teeth, two or three primary apical foramen constitute the radicular trunk (according to the number of roots and their

\footnotetext{
*Correspondence to:

Freddy Moreno

Faculty of Health Sciences

Pontificia Universidad Javeriana Cali

Colombia

fmorenog@javerianacali.edu.co
} 
position). Each root grows longitudinally as if it were a single-rooted tooth. Therefore, the existence of a number of roots higher than normal is associated with hyperactivity of Hertwig's epithelial root sheath (HERS) (Holtzman, 1997) or its partial pathological degeneration, which causes an invagination by the dental papilla inducing an accessory root (Sohn et al., 2014).

This paper reports the case of skeletonized human remains that were identified using antemortem-postmortem dental comparison, due to the presence of a bilateral mandibular two-rooted deciduous canine. Also presented is a review of the clinical literature on two-rooted canines. The goal of this paper is to demonstrate the application of dental anthropology (i.e., dental morphological variations) in the forensic dental identification processes.

\section{Forensic Odontology}

The process of identifying humans has particular relevance in human societies, because every single individual has an identity that must be conclusively proven at the time of death for social, cultural, religious, legal, and economic purposes. Usually, the legal life begins with a birth certificate and ends with the death certificate (Mertz, 1977). In the forensic sciences and during criminal investigations, investigators, prosecutors, and forensic experts (including the dentist) must interpret and classify the information collected. A careful examination of the soft and hard tissues of the stomatognathic system provides physical evidence that helps to establish the identity of a person (Krishan et al., 1997). Dental analyses and scrutiny of the soft and hard tissues that make up the stomatognathic system document physical evidence and/or injuries. If these are documented, it may help to establish the identity of an individual, to refute or confirm a testimony, or objectively link a victimizer with the victim and the crime scene; such as part of the comprehensive forensic analysis of a corpse and related elements within the context of each particular case (Whittaker, 1995).

Teeth are used as an identification tool in forensic odontology investigations. Their high identification value relies on the number of teeth, pathological conditions, restorations, dental materials used, prostheses, and implants. Therefore, if a set of remains is missing teeth, it can be difficult to identify the individual (Krishan et al, 1997; Whittaker, 1995; Rothwell, 2001; Pretty \& Sweet, 2001a, 2001b). Overall, dental identification is based on a comparison between the antemortem and postmor- tem record, which provides the forensic odontologist with enough distinctive features to make a positive identification (Pretty \& Sweet, 2001a, 2001b). Such characteristics are scientifically supported by the morphological individuality of the skeleton and teeth. This identification process can be comparative through analyses of antemortem dental records (medical history, dental chart, periodontal chart, radiographs, study models, cephalometric analysis, treatment plan, etc.) with postmortem and anthropological data. After performing the postmortem dental record of an unidentified individual or unknown set of human remains and having circumstantial evidence to suggest the possible identity of these, the next step is to obtain a dental medical history to collate postmortemantemortem dental records. Which, according to the American Board of Forensic Odontology (1994) and supported by national and international law, allows the establishment of a positive (total coincidence), possible (compatibility), insufficient (inadequate information available), or exclusive (incoherence and incompatibility) identification in a particular case.

\section{Case History}

A male minor with a chronological age of 5 years was reported missing. The initial search to find this minor was unsuccessful. Despite this, enquires in rural forensic units about cases of unidentified persons were made, finding out that in one of them, a set of unknown human skeletal remains was reported. The remains were found in a sugarcane plantation on the same date. The clothing worn by the individual on the day of his disappearance was found to be compatible with those on the skeletal remains. With this circumstantial evidence, the odontological medical history was obtained. This antemortem dental history did not contain radiographic images of the individual; however, the dentist noted in the chart the presence of deciduous lower two-rooted canines. A dental comparison was performed for the process of forensic identification. During which two reliable characteristics were discovered: The presence of deciduous lower two-rooted canines (Figures 1 and 2), whose interradicular septum was evident in the alveolar process of the mandible (Figure 3). In the postmortem radiographs of the deciduous canines it was possible to observe the presence of a root canal in every root and one pulp chamber in the crown of the tooth (Figure 4). In the dental clinical setting, Vertucci (2005) classified the number of roots and the number, shape, and configuration of the root ca- 


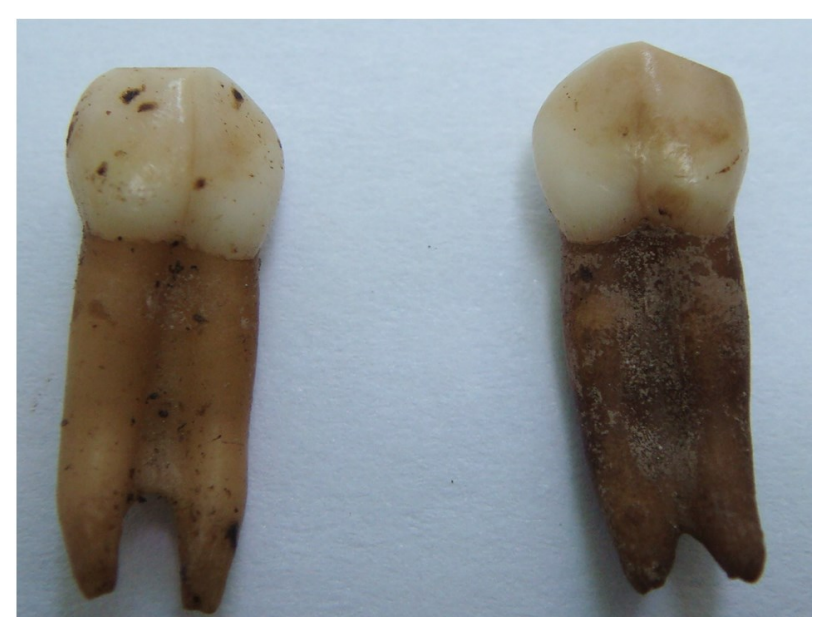

Figure 1. Deciduous lower two-rooted canines. Buccal view.

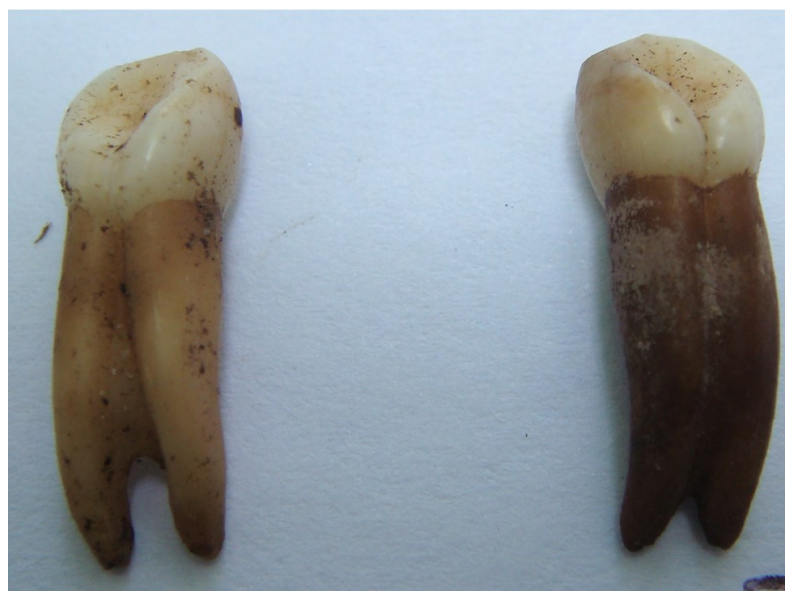

Figure 2. Deciduous lower two-rooted canines. Lingual view.

nals for diagnostic and endodontic therapeutic purposes. In such a way, according to the configuration of the pulp chamber of the tooth and root canals, the case reported is classified as a type I, where each root has a single canal that ends in its own apical foramen. Also, according to Turner et al. (1991) the case was classified as a mandibular two-rooted canine. Turner et al. (1991) standardized the observation of the number of roots of the mandibular canines, in which there are one or two roots, where the second one -usually a small, conical-shaped root directed towards lingual surfaceis separated from the root trunk at the middle third.

These features were sufficient to constitute reliable markers to positively identify the individual, despite the absence of radiographs.

\section{Systematized Search of the Literature}

A systematic review of the literature in PubMed (a

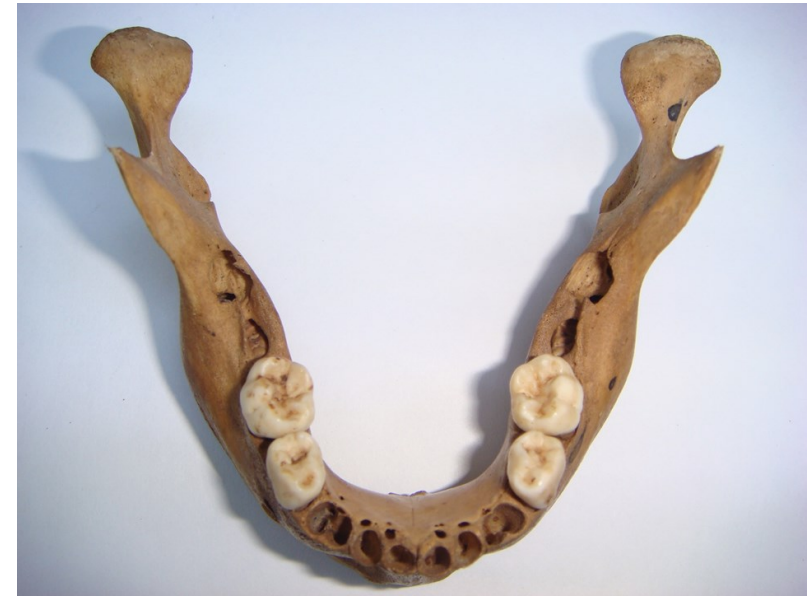

Figure 3. In alveolar process of the deciduous lower two-roots canines of the mandible is evident the interradicular septum.

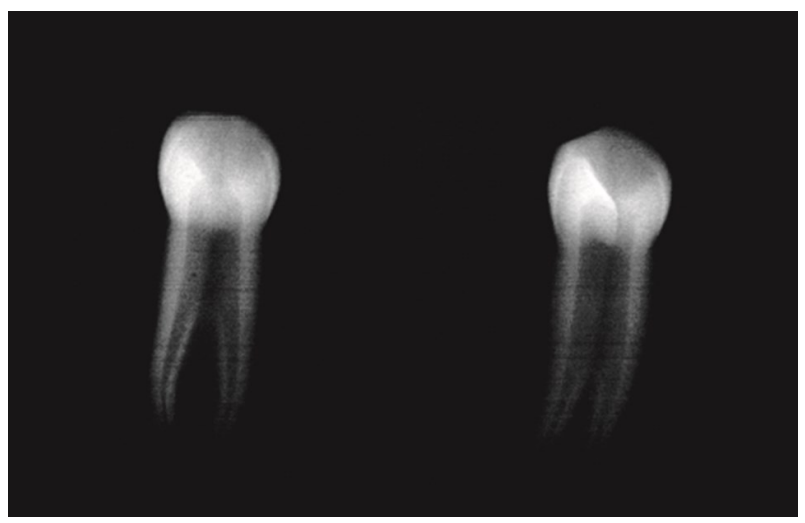

Figure 4. Postmortem radiography of the deciduous lower two-rooted canines.

free-access search engine to MedLine database of The United States National Library of Medicine) was performed through the combination of health science descriptors: "cuspid" and "tooth root", combined with the Boolean operators: "+" and "\&", which were located in the Medical Subject Headings (MeSH). Publications describing the presence of two-rooted canines were considered, in order to support the discussion of a case report of an individual with deciduous mandibular tworooted canines.

\section{Results}

Twenty-five publications fill the inclusion criteria, and were classified by year, type of tooth (deciduous or permanent, maxillary or mandibular canines), expression (unilateral or bilateral), sex (female or male), purpose of publication, and other important considerations (Table 1). There was only one report in which a description was performed 
Table 1. Reports of two-rooted canines in the literature. $U=u p p e r, L=l o w e r$

\begin{tabular}{|c|c|c|c|c|c|c|c|}
\hline Authors & Year & $\begin{array}{l}\text { Perma- } \\
\text { nent } \\
\text { Tooth }\end{array}$ & Expression & Gender & $\begin{array}{l}\text { Number of } \\
\text { roots/ } \\
\text { canals }\end{array}$ & Objective & Considerations \\
\hline $\begin{array}{l}\text { Rahmatulla } \\
\text { \& Wyne }\end{array}$ & 1993 & $\mathrm{LC}$ & $\begin{array}{l}\text { Unilateral } \\
\text { (right) }\end{array}$ & Female & $\begin{array}{l}\text { Two roots / two } \\
\text { canals }\end{array}$ & $\begin{array}{l}\text { Case re- } \\
\text { port }\end{array}$ & $\begin{array}{l}\text { The description of the distribution in } \\
\text { roots canals is performed }\end{array}$ \\
\hline Heling et al. & 1995 & $\mathrm{LC}$ & $\begin{array}{l}\text { No report- } \\
\text { ing }\end{array}$ & $\begin{array}{l}\text { No report- } \\
\text { ing }\end{array}$ & $\begin{array}{l}\text { Two roots / } \\
\text { three canals }\end{array}$ & $\begin{array}{l}\text { Case re- } \\
\text { port }\end{array}$ & $\begin{array}{l}\text { According to the authors this is the first } \\
\text { time a mandibular canine three canals }\end{array}$ \\
\hline Ouellet & 1995 & $\mathrm{LC}$ & $\begin{array}{l}\text { No report- } \\
\text { ing }\end{array}$ & $\begin{array}{l}\text { No report- } \\
\text { ing }\end{array}$ & $\begin{array}{l}\text { Two roots / two } \\
\text { canals }\end{array}$ & $\begin{array}{l}\text { Descrip- } \\
\text { tive study }\end{array}$ & $\begin{array}{l}806 \text { canines were examined } 95 \% \text { of } \\
\text { which has a root and } 5 \% \text { two roots }\end{array}$ \\
\hline $\begin{array}{l}\text { Orguneser \& } \\
\text { Kartal }\end{array}$ & 1998 & $\mathrm{LC}$ & $\begin{array}{l}\text { No report- } \\
\text { ing }\end{array}$ & $\begin{array}{l}\text { No report- } \\
\text { ing }\end{array}$ & $\begin{array}{l}\text { Two roots / } \\
\text { three canals(two } \\
\text { apical foramen) }\end{array}$ & $\begin{array}{l}\text { Case re- } \\
\text { port }\end{array}$ & $\begin{array}{l}\text { The description of the distribution in } \\
\text { roots canals is performed }\end{array}$ \\
\hline $\begin{array}{l}\text { D’Arcangelo } \\
\text { et al. }\end{array}$ & 2001 & $\mathrm{LC}$ & $\begin{array}{l}\text { Unilateral } \\
\text { (right) }\end{array}$ & Female & $\begin{array}{l}\text { Two roots / two } \\
\text { canals }\end{array}$ & $\begin{array}{l}\text { Case re- } \\
\text { port }\end{array}$ & $\begin{array}{l}\text { The description of root canal treatment is } \\
\text { performed in decayed tooth }\end{array}$ \\
\hline Alapati et al. & 2006 & UC & $\begin{array}{l}\text { Unilateral } \\
\text { (right) }\end{array}$ & Male & $\begin{array}{l}\text { One root / two } \\
\text { canals }\end{array}$ & $\begin{array}{l}\text { Case re- } \\
\text { port }\end{array}$ & $\begin{array}{l}\text { The description of root canal treatment is } \\
\text { performed in decayed tooth }\end{array}$ \\
\hline $\begin{array}{l}\text { Bolla \& Ka- } \\
\text { vuri }\end{array}$ & 2009 & UC & $\begin{array}{l}\text { Unilateral } \\
\text { (left) }\end{array}$ & Female & $\begin{array}{l}\text { Two roots / two } \\
\text { canals }\end{array}$ & $\begin{array}{l}\text { Case re- } \\
\text { port }\end{array}$ & $\begin{array}{l}\text { The description of root canal treatment is } \\
\text { performed in decayed tooth }\end{array}$ \\
\hline Wang et al. & 2009 & $\mathrm{LC}$ & $\begin{array}{l}\text { Unilateral } \\
\text { (right) }\end{array}$ & Female & $\begin{array}{l}\text { Two roots / two } \\
\text { canals }\end{array}$ & $\begin{array}{l}\text { Case re- } \\
\text { port }\end{array}$ & $\begin{array}{l}\text { The description of the distribution in root } \\
\text { canals and the root canal treatment in }\end{array}$ \\
\hline $\begin{array}{l}\text { Victorino et } \\
\text { al. }\end{array}$ & 2009 & $\mathrm{LC}$ & Bilateral & Female & $\begin{array}{l}\text { Two roots / two } \\
\text { canals }\end{array}$ & $\begin{array}{l}\text { Case re- } \\
\text { port }\end{array}$ & $\begin{array}{l}\text { The presentation of a case of bilateral } \\
\text { mandibular canines with two canals and }\end{array}$ \\
\hline Oporto et al. & 2010 & $\mathrm{LC}$ & $\begin{array}{l}\text { Unilateral } \\
\text { (left) }\end{array}$ & Female & $\begin{array}{l}\text { Two roots / two } \\
\text { canals }\end{array}$ & $\begin{array}{l}\text { Case re- } \\
\text { port }\end{array}$ & $\begin{array}{l}\text { The description of root canal treatment is } \\
\text { performed in decayed tooth }\end{array}$ \\
\hline Andrei et al. & 2010 & $\mathrm{LC}$ & $\begin{array}{l}\text { Unilateral } \\
\text { (right) }\end{array}$ & Female & $\begin{array}{l}\text { Two roots / two } \\
\text { canals }\end{array}$ & $\begin{array}{l}\text { Case re- } \\
\text { port }\end{array}$ & $\begin{array}{l}\text { The description of the distribution in root } \\
\text { canals is performed }\end{array}$ \\
\hline Andrei et al. & 2011 & $\mathrm{LC}$ & $\begin{array}{l}\text { Unilateral } \\
\text { (right) }\end{array}$ & Female & $\begin{array}{l}\text { Two roots / two } \\
\text { canals }\end{array}$ & $\begin{array}{l}\text { Case re- } \\
\text { port }\end{array}$ & $\begin{array}{l}\text { The description of the conventional root } \\
\text { canal treatment and apical surgery }\end{array}$ \\
\hline $\begin{array}{l}\text { Fonseca et } \\
\text { al. }\end{array}$ & 2011 & $\mathrm{LC}$ & $\begin{array}{l}\text { Unilateral } \\
\text { (left) }\end{array}$ & Male & Two canals & $\begin{array}{l}\text { Case re- } \\
\text { port }\end{array}$ & $\begin{array}{l}\text { The description of root canals treatment } \\
\text { of bifurcation lesion and vertical loss of }\end{array}$ \\
\hline $\begin{array}{l}\text { Bolla \& Ka- } \\
\text { vuri }\end{array}$ & 2011 & UC & $\begin{array}{l}\text { Unilateral } \\
\text { (left) }\end{array}$ & Female & $\begin{array}{l}\text { One root / two } \\
\text { canals }\end{array}$ & $\begin{array}{l}\text { Case re- } \\
\text { port }\end{array}$ & $\begin{array}{l}\text { The description of root canals treatment } \\
\text { is performed in decayed tooth }\end{array}$ \\
\hline Gaikwad & 2011 & $\mathrm{LC}$ & $\begin{array}{l}\text { Unilateral } \\
\text { (left) }\end{array}$ & Female & $\begin{array}{l}\text { Two roots / two } \\
\text { canals }\end{array}$ & $\begin{array}{l}\text { Case re- } \\
\text { port }\end{array}$ & $\begin{array}{l}\text { The description of root canals treatment } \\
\text { is performed in decayed tooth }\end{array}$ \\
\hline $\begin{array}{l}\text { Bhardwaj \& } \\
\text { Bhardwaj }\end{array}$ & 2011 & $\mathrm{LC}$ & $\begin{array}{l}\text { Unilateral } \\
\text { (right) }\end{array}$ & Female & $\begin{array}{l}\text { Two roots / two } \\
\text { canals }\end{array}$ & $\begin{array}{l}\text { Case re- } \\
\text { port }\end{array}$ & $\begin{array}{l}\text { The description of root canals treatment } \\
\text { by recurrent tooth decay due to restora- }\end{array}$ \\
\hline Moogi et al. & 2012 & $\mathrm{LC}$ & $\begin{array}{l}\text { Unilateral } \\
\text { (right) }\end{array}$ & Female & $\begin{array}{l}\text { Two roots / two } \\
\text { canals }\end{array}$ & $\begin{array}{l}\text { Case re- } \\
\text { port }\end{array}$ & $\begin{array}{l}\text { The description of root canals treatment } \\
\text { is performed }\end{array}$ \\
\hline Ferreira et al. & 2012 & $\mathrm{LC}$ & $\begin{array}{l}\text { Unilateral } \\
\text { (right) }\end{array}$ & $\begin{array}{l}\text { No report- } \\
\text { ing }\end{array}$ & $\begin{array}{l}\text { Two roots / two } \\
\text { canals }\end{array}$ & $\begin{array}{l}\text { Case re- } \\
\text { port }\end{array}$ & $\begin{array}{l}\text { Morphological description of the tooth } \\
\text { roots for forensic identification is per- }\end{array}$ \\
\hline Kaul et al. & 2012 & $\mathrm{LC}$ & $\begin{array}{l}\text { Unilateral } \\
\text { (left) }\end{array}$ & Female & $\begin{array}{l}\text { Two roots / two } \\
\text { canals }\end{array}$ & $\begin{array}{l}\text { Case re- } \\
\text { port }\end{array}$ & $\begin{array}{l}\text { Morphological description of the dilacer- } \\
\text { ation of the two roots and their respective } \\
\text { root canals treatment is performed }\end{array}$ \\
\hline He et al. & 2013 & $\mathrm{LC}$ & Bilateral & Male & $\begin{array}{l}\text { One root / mul- } \\
\text { tiples } \\
\text { canals }\end{array}$ & $\begin{array}{l}\text { Letter to } \\
\text { the editor }\end{array}$ & $\begin{array}{l}\text { Presentation of a case of bilateral mandib- } \\
\text { ular canines with multiple canals, root } \\
\text { canals treatment and restoration of ante- } \\
\text { rior teeth is performed }\end{array}$ \\
\hline $\begin{array}{l}\text { Ramírez- } \\
\text { Sotelo et al. }\end{array}$ & 2013 & $\mathrm{LC}$ & $\begin{array}{l}\text { Unilateral } \\
\text { (right) }\end{array}$ & Female & $\begin{array}{l}\text { Two roots / two } \\
\text { canals }\end{array}$ & $\begin{array}{l}\text { Case re- } \\
\text { port }\end{array}$ & $\begin{array}{l}\text { Morphological description of roots using } \\
\text { computed tomography was performed }\end{array}$ \\
\hline $\begin{array}{l}\text { Fuentes \& } \\
\text { Borie }\end{array}$ & 2013 & $\mathrm{LC}$ & Bilateral & Female & $\begin{array}{l}\text { Two roots / two } \\
\text { canals }\end{array}$ & $\begin{array}{l}\text { Case re- } \\
\text { port }\end{array}$ & $\begin{array}{l}\text { Morphological description of roots using } \\
\text { conventional radiography was performed }\end{array}$ \\
\hline Chawla et al. & 2013 & UC & $\begin{array}{l}\text { Unilateral } \\
\text { (left) }\end{array}$ & Female & $\begin{array}{l}\text { One root / two } \\
\text { canals }\end{array}$ & $\begin{array}{l}\text { Case re- } \\
\text { port }\end{array}$ & $\begin{array}{l}\text { The description of root canals treatment } \\
\text { in decayed tooth is performed }\end{array}$ \\
\hline $\begin{array}{l}\text { Mithunjith.\& } \\
\text { Borthakur }\end{array}$ & 2013 & $\mathrm{LC}$ & $\begin{array}{l}\text { Unilateral } \\
\text { (left) }\end{array}$ & Female & $\begin{array}{l}\text { Two roots / two } \\
\text { canals }\end{array}$ & $\begin{array}{l}\text { Case re- } \\
\text { port }\end{array}$ & $\begin{array}{l}\text { The description of root canals treatment } \\
\text { in decayed tooth is performed }\end{array}$ \\
\hline $\begin{array}{l}\text { Arora, Nikh- } \\
\text { il \& Gupta }\end{array}$ & 2013 & $\mathrm{LC}$ & $\begin{array}{l}\text { Unilateral } \\
\text { (left) }\end{array}$ & Female & $\begin{array}{l}\text { One root / two } \\
\text { canals }\end{array}$ & $\begin{array}{l}\text { Case re- } \\
\text { port }\end{array}$ & $\begin{array}{l}\text { The description of root canals treatment } \\
\text { in decayed tooth is performed }\end{array}$ \\
\hline
\end{tabular}


for forensic identification purposes; the primary means of description were conventional radiography and computed tomography. The descriptions corresponded to four cases of permanent maxillary canines with left unilateral expression; the other 21 cases were permanent mandibular canines, with right unilateral expression (10 cases); left unilateral expression (9 cases) and bilateral expression ( 3 cases). Nineteen cases in female and three in male subjects were reported; two-root expression, each root with a canal, was predominant (18 cases). There were no reports in deciduous dentition.

\section{Discussion}

Usually, the maxillary and mandibular canines are considered as a single-rooted tooth, given the high prevalence of $93.48 \%$ of this condition (Oporto et al., 2010), However, Brothwell -cited by Ferreira et al. (2012)- collected several reports on the prevalence of two-rooted canine expression, finding no population significant differences related to ethnic pattern, bilateral expression, or sexual dimorphism. According to the literature, the morphological variation related to the number of roots is $1 \%$ to $2 \%$ for the maxillary canines, and $1.3 \%$ to $15 \%$ for the mandibular canines, mainly the two roots and two canals expression with one canal per root (Bolla \& Kavuri, 2011). Exceptionally, mandibular two-rooted canines and three canals have been reported (Heling et al., 1995), as well as, two-rooted canines, three canals, and two apical foramina (Orguneser \& Kartal, 1998), single-rooted canines and two canals (Arora, 2013), and single-rooted canines with multiple canals (He et al., 2014). Another important feature is that in most cases of canines with two roots these are distributed in a buccal and lingual direction (Ferreira et al, 2012); however, in this case report, the roots were distributed in a mesial and distal direction. Thus, most of the reports suggest that canines with two roots correspond to a shape abnormality of the tooth during morphogenesis, related to an alteration of the HERS. A tooth root develops from the HERS and around the dental papilla underneath the dental follicle, until it completely cover the papilla in the primary apical foramen (Thomas, 1995).

The systematic review of the literature predominantly described canines with more than one root to demonstrate the clinical difficulty of root canal treatment of these teeth after the development of pathological processes (usually caries). This difficulty is mainly related to the identification of the longitudinal course of the canals due to superimposed radiographic images, the narrowness of the canals, complications from filling them, and apical sealing (Bolla \& Kavuri, 2009). Radiographic images were used for forensic purposes, in order to identify features that allow the identification of the decedent from the shape, size, and number of roots of the teeth (Senn \& Weems, 2013). Thus, Ferreira et al. (2012) reported a case of a mandibular tworooted canine with two canals in a decomposing set of remains. However, although the victim was not identified by the dental setting, the authors state that given the low prevalence of this dental trait, could eventually become a valuable tool for forensic odontology identification.

\section{Conclusions}

In this case report, it is evident that the study of dental morphological variation from the point of view of dental anthropology -as in the case of bilateral expression of mandibular two-rooted canines- constitutes a reliable marker that allows a positive identification of an individual during antemortem-postmortem comparisons in the field of forensic odontology. In the literature, the expression of bilateral lower two-rooted canines was found to be rare. In this case, the observation and recording of the presence of a bilateral temporal expression of lower two-rooted canines contributed to the process of dental forensic identification, specifically the information registered by the dentist in the dental chart. The medical history had no radiographic records.

\section{REFERENCES}

Alapati, S., Zaatar, E. I., Shyama, M. \& Al-Zuhair, N. (2006). Maxillary canine with two root canals. Medical Principles and Practice, 15(74), 6.

American Board of Forensic Odontology ABFO

(1994). Body identification guidelines. The Journal of the American Dental Association, 125(9), 1244-54.

Andrei, O. C., Mărgărit, R. \& Dăguci, L. (2010). Treatment of a mandibular canine abutment with two canals. Romanian Journal of Morphology and Embryology, 51(3), 565-8.

Andrei, O. C., Mărgărit, R. \& Gheorghiu, I.M. (2011). Endodontic treatment of a mandibular canine with two roots. Romanian Journal of Morphology and Embryology, 52(3), 923-6.

Arora, V., Nikhil, V. \& Gupta, J. (2013). Mandibular canine with two root canals: An unusual case report. International Journal of Stomatological Research, 2(1), 1-4.

Bhardwaj, A. \& Bhardwaj, A. (2011). Mandibular canines with two roots and two canals: A case report. International Journal of Dental Clinics, 3(3), 
77-8.

Bolla, N. \& Kavuri, S. R. (2009). A case of unusual root morphology: Maxillary canine with two roots. Journal of International Clinical Dental Research Organisation, 1(3), 70-5.

Bolla, N. \& Kavuri, S. R. (2011). Maxillary canine with two root canals. Journal of Conservative Dentistry, 14(1), 80-2.

Chawla, A., Sujlana, A. \& Chawla, H. S. (2013). Endodontic management of maxillary canine with two root canals. Indian Journal of Dentistry, 5 (suppl.), 112-5.

D'Arcangelo, C., Varvara, G. \& De Fazio, P. (2001). Root canal treatment in mandibular canines with two roots: a report of two cases. International Endodontic Journal, 34(4), 331-4.

Ferreira, R., Machado, M., de Lucena, T., Vieira, R. \& de Acevedo, D. E. (2012). Anatomical variations in the permanent mandibular canine: forensic importance. Revista Sul-Brasileira de Odontologia, 9(4), 468-73.

Fonseca, D. R., Sena, L. G., Santos, M. H. \& Goncalves, P. F. (2011). Furcation lesion in a mandibular canine. General Dentistry, 59(4), 173-7.

Fuentes, R. \& Borie, E. (2013). Bilateral two-rooted mandibular canines in the same individual: a case report. International Journal of Odontostomatology, 7(3), 471-3.

Gaikwad, A. (2001). Endodontic treatment of mandibular canine with two canals: A case report. International Journal of Dental Clinics, 3(1), 118-9.

He, L. B., Shao, M. Y., Xu, X. \& Li, J. Y. (2014). Bilateral mandibular canines with single root and multiple canals. Journal of Dental Sciences, 9(2), 199-201.

Heling, I., Gottlieb-Dadon, I. \& Chandler, N. P. (1995). Mandibular canine with two roots and three root canals. Dental Traumatology, 11(6), 301 $-2$

Hillson, S. (1996). Dental anthropology. London: Cambridge University Press.

Holtzman, L. (1997). Root canal treatment of a mandibular canine with three root canals. Case report. International Endodontic Journal, 30, 291-3.

Kaul, R., Farooq, R., Purra, A. R., Bhagat, R. K. \& Khateeb, S. U. (2012). Two rooted mandibular canine with severe dilacerations. International Journal of Clinical cases and Investigations, 4(1), 759.

Kraus, B. S., Jordan, R. E. \& Abrams, L. (1969). Dental anatomy and occlusion. St. Louis: Lippincott Williams \& Wilkins.

Krishan, K., Vashisht, R. N. \& Vij, K. (1997). Teeth in personal identification. Medico-Legal Update, 2
(1-2), 9-11.

Mertz, C. A. (1977). Dental identification. Dental Clinics of North America, 21(1), 47-67.

Mithunjith, K. \& Borthakur, B. J. (2013). Endodontic management of two rooted mandibular canine. e-Journal of Dentistry, 3(1), 339-42.

Moogi, P. P., Hegde, R. S., Prashanth, B. R. et al. (2012). Endodontic treatment of mandibular canine with two roots and two canals. Journal of Contemporary Dental Practice, 13(6), 902-4.

Oporto, V. G. H., Fuentes, F. R. E. \& Soto, P. C. C. (2010). Variaciones anatómicas radiculares y sistemas de canales. International Journal of Morphology, 28(3), 945-50.

Orguneser, A. \& Kartal, N. (1998). Three canals and two foramina in a mandibular canine. Journal of Endodontics, 24(6), 444-5.

Ouellet, R. (1995). Mandibular permanent cuspids with two roots. Journal of the Canadian Dental Association, 61(2), 159-61.

Pretty, I. A. \& Sweet, D. (2001). A look at forensic dentistry - Part 1: The role of teeth in the determination of human identity. British Dental Journal, 109(7), 359-66.

Pretty, I. A. \& Sweet, D. (2001). A look at forensic dentistry - Part 2: Teeth as weapons of violence identification of bitemark perpetrators. British Dental Journal, 190(8), 415-8.

Rahmatulla, M. \& Wyne, A. H. (1993). Bifid roots in a mandibular canine: report of an unusual case. The Saudi Dental Journal, 5(2), 77-8.

Ramírez-Sotelo, L. R., Sampaio, F., Roque-Torres, G. D., Queiroz de Freitas, D., de Almeida, S. M. \& Bóscolo, F. N. (2013). Canino mandibular con dos raíces. Revista Cubana Estomatología, 50(2), 211-8.

Rothwell, B. R. (2001). Principles of dental identification. Dental Clinics of North America, 2001, 45 (2), 253-70.

Senn, D. R. \& Weems, R. A. (2013). Manual of forensic odontology. Florida: CRC Press.

Sohn, W. J., Choi, M. A., Yamamoto, H. et al. (2014). Contribution of mesenchymal proliferation in tooth root morphogenesis. Journal of Dental Research, 93(1), 78-83.

Thomas, H. F. (1995). Root formation. International Journal of Developmental Biology, 39, 2317.

Turner II, C. G., Nichol, C. R. \& Scott, G. R. (1991). Scoring procedures for key morphological traits of the permanent dentition: The Arizona State University dental anthropology system. In Kelly M.A. \& Larsen C.S .(Eds.), Advances in dental anthropology (pp. 13-31). New York: Wiley-Liss. 
its relationship to endodontic procedures. Endodontic Topics, 10, 3-29.

Victorino, F. R., Bernardes, R. A., Baldi, J. V. et al. (2009). Bilateral mandibular canines with two roots and two separate canals - Case Report. Brazilian Dental Journal, 20(1), 84-6, 2009.

Wang, L., Zhang, R. \& Peng, B. (2009). Clinical Features and Treatment of Mandibular Canines with Two Root Canals: Two Case Reports. Chinese Journal of Dental Research, 12(1), 61-2.

Whittaker, D. K. (1995). Forensic dentistry in the identification of victims and assailants. Journal of Clinical Forensic Medicine, 2, 145-51. 